\title{
NILAI PENDIDIKAN KARAKTER DALAM NOVEL MAYSURI KARYA NADJIB KARTAPATI Z
}

\author{
Dian Pratiwi ${ }^{1}$, Atiqa Sabardila ${ }^{2}$ \\ Universitas Muhammadiyah Surakarta \\ Pendidikan Bahasa dan Sastra Indonesia, FKIP, Surakarta \\ A310190059@student.ums.ac..id
}

\begin{abstract}
Abstrak
Penelitian ini bertujuan mendeskripsikan nilai Pendidikan karakter yang terdapat dalam novel Maysuri Karya Nadjib Kartapati Z serta memotivasi para pembaca dan mampu mengembangkan kompetensi siswa dalam memahami tokoh dalam novel. Penelitian ini menggunakan pendekatan kualitatif. Data yang dikumpulkan menggunakan Teknik membaca keseluruhan cerita dalam novel, kemudian mencari dan mengumpulkan data berupa kalimat yang terdapat dalam novel, setelah itu melakukan klasifikasi terhadap data yang sudah terkumpul dan menjelaskan data tersebut. Hasil penelitian menunjukan bahwa terdapat 12 nilai Pendidikan karakter dalam novel maysuri yaitu hidup sederhana,tanggung jawab, kasih sayang, berbakti kepada orangtua, rasa ingin tau, rajin,religious,peduli,jujur,empati, kreatif dan gemar membaca. Berdasarkan data yang ditemukan novel Maysuri karya Kartapati Z, cerita dalam novel Maysuri Kartapati $Z$ ini dapat memotivasi pembaca dalam berperilaku dan bermasyarakat serta dapat membantu peserta didik untuk menjadikan bahan materi pembelajaran karya sastra Bahasa Indonesia utamanya dalam memahami unsur instrinsik ekstrinsik dan unsur kebahasaan dalam novel ini, serta dapat mengembangkan kompetensi siswa dalam memahami suatu karakter tertentu pada cerita serta dapat mengambil nilai Pendidikan karakter yang terkandung dalam novel karena dalam novel Maysuri karya Kartapati $Z$ terdapat banyak nilai karakter yang dapat dijadikan contoh dalam lingkungan keluarga atau masyarakat serta mengembangkan kompetensi siswa dalam memahami karya sastra dalam suatu materi pembelajaran.
\end{abstract}

Kata Kunci : Pendidikan Karakter, Kompetensi, Pengembangan Materi

\section{PENDAHULUAN}

Karya sastra adalah ciptaan yang disampaikan dengan komunikatif tentang maksud penulis untuk tujuan estetika dalam cerita yang diperlihatkan. Karya sastra adalah ungkapan isi hati seseorang yang berupa pemikiran, perasaan, ide,semangat,pengalaman yang ada dalam diri seseorang yang dituliskan dalam bentuk gambaran kehidupan yang dapat memberikan pandangan untuk pembaca (Sari, 27). Dalam karya sastra pengarang juga menceritakan suatu peristiwa yang dialami di kehidupan sehari-hari dengan merekam peristiwa kebudayaan yang ada dengan menggunakan objek manusia dan masyarakat, sehingga karya sastra yang berbentuk novel selalu memberikan suatu nilai-nilai tertentu dalam rangkaian cerita 
yang dirangkai oleh pengarang tersebut (Tansliova, 2018). Karya sastra menerima dan mampu memberi pengaruh kepada masyarakat, salah satunya dengan sastra novel. Novel adalah salah satu bentuk karya fiksi yang dapat menyampaikan permasalahan kehidupan yang bersifat kompleks (Ermina Waruwu, 2020).

Menurut (Thahar, 2019) novel merupakan suatu alat yang dapat digunakan untuk mewujudkan tujuan Pendidikan karakter sehingga dengan membaca para pembaca novel dapat mengetahui hal-hal positif dari cerita yang telah disampaikan oleh pengarang kepada pembaca.Kemudian Perkembangan sastra puisi semakin berpindah tahun semakin banyak yang membaca puisi karena puisi merupakan salah satu bacaan yang diminati oleh anak remaja karena dalam puisi tersajikan suatu cerita yang dapat menarik minat baca para pembaca. Dengan hal ini karya sastra yang hadir di masyarakat dapat dijadikan suatu bukti karena karya sastra dapat menjadi suatu bagian dari kehidupan manusia yang dpat dinikmati oleh pembaca masyarakat (Arifin, 2019).Dalam novel sendiri terkandung suatu hikmah dan dapat diambil sisi positif dari tokoh-tokoh yang diceritakan dalam novel. Unsur yang terdapat dalam novel selain tokoh yaitu latar,plot,sudut pandang serta amanat.
Amanat dalam cerita novel dapat dijadikan sebagai Pendidikan karakter yang bisa dijadikan motivasi dalam kehidupan. Oleh karena itu, karya sastra juga dapat dikatakan karya sastra memiliki hubungan sangat erat dengan Pendidikan karakter,karena jika dilihat dengan baik karya sastra dapat menjadi sarana penanaman nilai Pendidikan karakter (Achmad Sultoni, 2020).

Dalam novel terdapat pendidikan karakter yang dapat dijadikan contoh dalam keluarga maupun dalam keluarga. Sebelumnya, arti Pendidikan merupakan suatu kebutuhan manusia untuk tumbuh menjadi manusia yang baik, berakal dan berbudi pekerti yang luhur, sedangkan karakter yaitu ciri khas yang dimiliki oleh suatu benda atau individu, ciri khas tersebut adalah asli dan mengakar pada kepribadian benda atau individu tersebut (Riko, 2021). Kemudian, Pendidikan karakter sendiri yaitu suatu bentuk kegiatan manusia yang melakukan Tindakan dengan mendidik dan diperuntukkan bagi generasi masa yang akan datang. Satuan Pendidikan juga telah menetapkan bahwa pembentuk nilai karakter bangsa terdapat 18 karakter yaitu yang bersumber dari agama,Pancasila, budaya serta tujuan Pendidikan nasional (Nasional, 2010). Tujuan Pendidikan karakter ialah sempurnanya hidup manusia 
sehingga bisa memenuhi segala keperluan hidup lahir dan batin yang kita dapat dari kodrat alam (Karimah, 2018). Selain itu, tujuan Pendidikan karakter digunakan untuk menguatkan serta mengembangkan pentingnya nilai kehidupan sehingga dapat menjadikan suatu pribadi yang khas seperti nilai yang sudah dikembangkan dan dapat mengoreksi Tindakan yang bertentangan dengan nilai yang sudah dikembangkan kemudian dapat menjalin komunikasi antar keluarga dan masyarakat (Alimin, 2017).

Dasar dari pemikiran pada Gerakan Pendidikan karakter adalah adanya perilaku yang menyimpang dari aturan seperti, kekerasan, korupsi, ketidaksopanan serta tidak adanya keadilan serta adanya etika kerja yang buruk, dan tidak adanya karakter yang dikatakan baik (Saptiana Sulastri, 2020). Maka dari itu seseorang yang memiliki karakter merupakan seseorang yang dapat dinilai bahwa dia memiliki kualitas moral yang positif (Rahmat Gunawan, 2018).

Sehingga penulis mengambil tema Pendidikan karakter dalam novel juga mempunyai tujuan agar karya sastra semakin berkembang pesat dan semakin dikenal dengan masyarakat umum serta baiknya terdapat suatu cerita yang dapat memotivasi para pembaca agar menjadi generasi yang maju dan berkarakter serta dapat membanggakan bangsa Indonesia.
Selain itu,juga dapat membuat para pembaca semakin paham dengan Bahasa indonesia yang digunakan dalam cerita atau karya sastra lain.dikarenakan Pendidikan karakter juga penting dalam membangun diri peserta didik sehingga dalam perkembangan teknologi tidak kehilangan sikap seperti disiplin, jujur, kerja keras, serta religius (Muhammad Rois Abdulfatah, 2018). Adapun tujuan penelitian ini ialah untuk dapat memotivasi pembaca, agar pembaca mengetahui di dalam novel Maysuri karya Kartapati Z terdapat pendidikan karakter yang dapat diambil.

\section{KAJIAN TEORI}

\section{Nilai Pendidikan Karakter}

Nilai Pendidikan yang terdapat dalam Novel Maysuri yaitu nilai Pendidikan peduli, kasih sayang, empati, religius, tanggungjawab, mencari tahu, jujur, berbakti kepada orangtua, kreatif,hidup sederhana, rajin serta membaca. Nilai Pendidikan sendiri merupakan suatu nilai yang dapat mebimbing kearah yang lebih baik seperti perilaku peduli, kasih sayang, empati, religius, tanggungjawab, mencari tahu, jujur, berbakti kepada orangtua, kreatif, hidup sederhana, rajin serta membaca. Sedangkan, Nilai Karakter adalah suatu nilai yang dapat berguna dalam kehidupan 
manusia sehingga karakter dapat dianggap penting dalam melakukan sosialisasi. Kemudian pendidikan karakter sendiri yaitu suatu tindakan yang diterapkan oleh manusia yang nantinya Pendidikan tersebut dapat digunakan untuk generasi selanjutnya.

\section{Novel}

Novel adalah suatu karangan cerita dari kehidupan seseorang yang menonjolkan atau melebihkan watak dan perilaku dalam tokoh tersebut. Watak tokoh yaitu suatu karakter yang dibangun dalam suatu cerita atau drama, watak sendiri terdiri dari protagonis, antagonis dan tritagonis, sedangkan perilaku yaitu suatu tindakan manusia di suatu lingkungan yang akan terwujud dalam bentuk pengetahuan dan sikap.

\section{METODE PENELITIAN}

Objek yang digunakan dalam penelitian ini adalah Novel Maysuri karya Nadjib Kartapati Z. yang diterbitkan Pustaka Alvabet 2016, berisi 316 halaman. Metode yang digunakan dalam penelitian adalah metode deskriptif kualitatif. Teknik yang digunakan untuk mengumpulan data yaitu dengan membaca secara keseluruhan cerita dalam novel maysuri karya Nadjib Kartapati Z, Kemudian mencari dan mengumpulkan data berupa kalimat yang nantinya dapat menjawab masalah dalam penelitian, setelah itu melakukan klasifikasi terhadap data-data yang telah terkumpul, kemudian memaparkan hasil data yang telah ditemukan serta membuat kesimpulan dari data penelitia.

\section{HASIL DAN PEMBAHASAN}

\subsection{Hasil}

Berdasarkan hasil data yang ditemukan terdapat dua belas Pendidikan karakter dalam novel Maysuri karya Nadjib Kartapati Z. Sebagai berikut uraian data yang ditemukan:

\section{Peduli}

Dalam cerita novel Maysuri Karya Nadjib Kartapati Z, kutipan yang ditemukan adalah peduli sosial. Peduli sosial yaitu suatu Tindakan yang selalu ingin memberi bantuan pada orang lain yang membutuhkan (Husna, 2020).

(1) "kemarin Pak Pras membesukku." (hlmn.16).

(2) "kedua, seluruh anggota Pak Sardi begitu baik terhadapku sehingga dua kebutuhanku yang terbilang pokok---sarapan pagi dan urusan cuciseterika-sering kali dihandel oleh mereka".(hlmn. 51)

(3) "hari ini aku sengaja menguntit Suryani pergi setelah menitipkan Maysuri 
padaseorang tetangga yang

baik hati dan menaruh rasa kasihan padauk”. (hlmn.65)

(4) "kami, sebagai orangtuanya, merasa prihatin dan sangat mengkhawatirkannya."

(hlmn.93)

Pada kutipan (1) menggambarkan perilaku peduli terhadap sesama. Kegiatan membesuk atau melihat kondisi seseorang dapat membuat hubungan antar tetangga atau teman terjalin dengan baik. Penulis memperlihatkan Tindakan dalam kutipan tersebut menunjukakan perilaku peduli terhadap sesama teman, keluarga ataupun tetangga. Kemudian pada kutipan (2) juga termasuk dalam peduli terhadap sesama manusia, karena pada kutipan tersebut menggambarkan keluarga pak Sardi yang membantu kebutuhan tokoh utama dalam kehidupan sehari-hari tanpa mengharap belas kasih, menurut penulis Tindakan termasuk kegiatan peduli dan terpuji karena saling membantu terhadap tetangga yang membutuhkan.

Setelah itu, kutipan (3) dan (4) menggambarkan bahwa suatu keluarga yang memperhatikan orang-orang dalam keluarga tersebut, sehingga penulis menyatakan kutipan tersebut termasuk dalam karakter peduli.

\section{Empati}

Empati adalah kemampuan untuk bisa mengerti atau memahami apa yang orang lain rasakan secara emosional. Selain itu, pengertian empati yaitu suatu identifikasi dari pengalaman yang dapat dirasakan dari pengalaman atau keadaan orang lain (Isnaniah, 2020). Dalam Novel Maysuri karya Nadjib Kartapati Z. terdapat karakter yang menunjukkan rasa empati yaitu:

(5) Hatiku trenyuh mendengar ratapan mamak.(hlmn 52)

Dari kutipan (5) tersebut menampilkan rasa empati kepada seorang ibu karena ibu sedang mengungkapkan perasaannya yang sedih karena mendengar cerita anaknya.

\section{Kasih sayang}

Dalam novel ini menceritakan kasih sayang bapak dan ibu dalam hal mengasuh dan membesarkan anak dari lahir sampai dewasa. Penjelasan ini terlihat dalam kutipan novel. Bunda dan Ayah tidak berhenti dalam membesarkan anakanaknya. Berikut gambaran dari penjelasan:

(6) "sepenuh kasih sayang Bunda menempelkan punggung telapak tangannya dikeningku. Persis seperti pada umumnya orang tua jika ingin 


$$
\begin{aligned}
& \text { mengetahui suhu badan } \\
& \text { anaknya yang masih } \\
& \text { kecil."(hlmn.3) }
\end{aligned}
$$

Pada data kutipan (6), terlihat gambaran bahwa perilaku Bunda yang menunjukan nilai kasih sayang. Tindakan dalam menempelkan telapak tangan dikening dapat menambah rasa kasih sayang dan khawatir dalam Kesehatan anak sehingga peran bunda tersebut menumbuhkan rasa kasing sayang. Pada kutipan ini, penulis menunjukkan tentang salah satu cara perilaku kasih sayang ibu terhadap anak.

\section{Religius}

Nilai Pendidikan religious yaitu suatu perilaku yang menjalankan ajaran agama sesuai perintah yang dianut serta dapat bertoleransi kepada agama lain (Fauliyah, 2020). Dalam penelitian (Tantri, 2017) religious adalah sikap atau perilaku yang melaksanakan kewajiban sesuai ajaran agama yang dipercaya serta menghargai pelaksanaan ibadah agama lain. Nilai Pendidikan karakter religius terdapat dalam kutipan novel Maysuri karya Nadjib Kartapati Z. yaitu:

(7) “ pada saat aku pasrah, tak berharap apapun mengenai lelaki yang akan mendampingi hidupku,menyerahkan sepenuhnya kepada Allah akan

jadi apa aku nanti,..."(hlmn.30)

(8) "Aku masih mencoba menguntai kalimat yang mulia dengan mengatakan bahwa sebaiknya kami bersyukur dengan rezeki yang kami peroleh itu. "(hlmn.63)

Penemuan data

menggambarkan bahwa perilaku tersebut menunjukkan nilai religious. Perilaku menyerahkan sepenuhnya kepada Allah merupakan suatu tindakan yang mulia karena semua yang ada didunia ini hanyalah milik Allah. Penulis menunjukkan nilai pendidikan karakter religius tentang berserah kejadian yang akan dilewati dan selalu mengingat sang maha pencipta.

Data ke(8) termasuk data religius dikarenakan tokoh dalam keadaan apapun tetap bersyukur dengan apa yang diperolehnya serta tidak sombong dengan hasil yang sudah diperoleh. Dalam kutipan ini pendidikan karakter yang dapat diperoleh yaitu selalu bersyukur dan selalu menerima rezeki dengan ikhlas.

\section{Tanggung Jawab}

Nilai karakter tanggung jawab
yaitu suatu perilaku seseorang dalam
melakukan tugas dan nilai kewajibannya
berdasarkan pada nilai yang berlaku di

Nilai karakter tanggung jawab 
masyarakat. Selain itu, tanggung jawab adalah sikap dan perilaku seseorang untuk melaksanakan tugas dan kewajiban yang seharusnya dilakukan terhadap diri sendiri, masyarakat, negara dan Tuhan Yang Maha Esa (Sri Utorowati, 2018). Nilai Pendidikan karakter tanggung jawab dalam Novel Maysuri karya Nadjib Kartapati Z terdapat dalam kutipan:

(9) "Praktis akulah yang mengasuh anakku, memandikannya, menyuapinya, dan meninabobokannya”.(hlmn.64)

(10) "Terpaksa aku belikan ia susu kaleng, kuseduh sendiri, kususui anakku dengan botol,kugendong-gendong supaya diam dan tertidur, sementara ibunya bertandang ke rumah tetangga dan ngerumpi disana." (hlmn.60)

$$
\text { Pada data (9) menunjukkan }
$$

karakter tanggungjawab karena pada perilaku mengasuh anak,memandikan dan menyuapi anak merupakan tanggung jawab seorang ayah dalam mendidik dan membesarkan anaknya sehingga tidak ibu saja yang mempunyai tanggung jawab itu melainkan kedua orangtua yang menjalankannya. Kemudian pada data (10) menggambarkan tindakan tanggungjawab orang tua kepada anak dan kutipan tersebut menceritakan bagaimana orangtua merawat anak dari kecil hingga menjadi seseorang yang sukses.

\section{Mencari tahu}

Rasa ingin tahu merupakan cara berpikir, sikap,dan perilaku yang mencerminkan penasaran dan keingintahuan terhadap segala hal yang dilihat,didengar dan dipelajari secara lebih mendalam (Utaminingsih, 2020). Berikut data yang didapat dalam novel Maysuri Kartapati Z :

(11) "Bunda memandangiku seakan dia sedang menelusuri pedalaman jiwaku”.(hlmn.74)

Pada data (11) termasuk karakter mencari tahu karena pada kalimat "sedang menelusuri pedalaman jiwa" merupakan Tindakan dalam mencari tau suatu kebohongan atau suatu kejujuran pada lawan bicara.

\section{Jujur}

Jujur merupakan suatu Tindakan yang berdasarkan dalam upaya untuk menjadikan orang tersebut dapat dipercaya dalam perkataan dan perbuatan (Teguh Alif Nurhuda, 2018). Tanpa kejujuran seseorang akan sulit mendapat suatu kemuliaan (Juanda, 2018). Dalam novel Maysuri karya Nadjib Kartapati Zterdapat kutipan tentang kejujuran terhadap lawan bicara, berikut data yang didapat: 
(12)

"Ternyata dia ibu kandung gue. Dia pernah jadi pelacur dan sekarang enggak jelas ada dimana".hlmn.85

Dalam data (12) menurut penulis termasuk kedalam nilai jujur karena pada tersebut menunjukkan kejujuran bahwa tokoh utama berbicara kepada lawan bicara bahwa ibu kandungnya dahulunya bekerja sebagai pelacur dan tokoh utama tidak tau tentang keberadaan ibunya karena ia sudah ditinggal sejak kecil.

\section{Berbakti kepada orang tua}

Dalam novel Maysuri karya Nadjib Kartapati Z pendidikan karakter berbakti kepada orang tua ditampilkan dalam kegiatan saat menemui ibu kandung maysuri sebagai tokoh utama dalam novel,dikarenakan sejak kecil maysuri sudah ditinggal oleh ibunya yang bekerja sebagai pelacur. Akan tetapi meskipun ibunya dulu bekerja sebagai pelacur dan dia ditinggal ibunya sekarang dia masih tetap menganggap ibu kandungnya yang harus ia hormati dan sayangi.

Ringkas cerita tersebut dapat diambil hikmah bahwa berbakti kepada orangtua yaitu dengan menghormati dan menyayangi serta memaafkan mereka meskipun mereka mempunyai suatu kesalahan yang besar mereka masih orangtua kita yang pernah melahirkan dan membesarkan kita sampai sekarang.

\section{Kreatif}

Kreatif merupakan suatu Tindakan yang dapat menghasilkan hasil baru dari ide yang telah dimiliki (Indar Agus Susilowati, 2019). Selain itu, kreatif adalah cara berfikir dalam melakukan sesuatu yang nantinya dapat menhasilkan penemuan baru dari hasil karya yang dimiliki (Andriani, 2019). Dalam novel Maysuri karya Nadjib Kartapati Z terdapat nilai kreatif dalam cerita berikut datanya:

(13) "Dua bagian yang berada ditengah,yang dihuni keluarga Pak Sardi,sudah dirombak sedemikian rupa dengan tiga kamar,dua diantara kamar itu untuk anak-anaknya.anyaman kawat yang berada didepan rumah Pak Sardi diganti dengan pintu dari papan-papan kayu karena bagian ini untuk berjualan jajanan $B u$ Sardi”.(hlmn.50)

Data (13) termasuk dalam karakter kreatif, karena dalam kutipan data tersebut melakukan Tindakan merombak suatu tempat menjadi beberapa bagian serta adanya perubahan tempat yang akan dijadikan tempat berjualan bagi tokoh yang memerankan. 


\section{Hidup sederhana}

(14) "saya sejak kecil penuh kekurangan. Bang ! hidup menderita dan serba paspasan...."hlmn.59

Data (14) menjelaskan bahwa tokoh tersebut mengalami kehidupan yang kekurangan sehingga semua serba kekurangan dan tokoh harus berhemat. Penulis menunjukkan tentang gambaran pendidikan hidup sederhana.

\section{Rajin}

Rajin adalah sifat manusia yang melakukan sesuatu hal dengan bersungguh-sungguh untuk mencapai tujuan tertentu. Novel Maysuri karya Nadjib Kartapati Zterdapat data yang mencerminkan rajin, berikut datanya:

"Bolehlah anda tanyakan apakah aku mampu hidup senang?maka jawabanku:Ya! Ada dua alasan. Dengan menabung setiap hari,uang kuliahku relative aman".(hlm.51)

Dalam data (15) tersebut termasuk dalam tindakan rajin dalam menabung karena dengan menabung kita dapat mempersiapkan hari kedepan lebih baik. Menabung adalah menyisihkan sebagian uang yang dimiliki untuk disimpan yang nantinya akan dipergunakan dalam suatu keperluan.

\section{Membaca}

Membaca merupakan suatu kegiatan yang memerlukan waktu luang dalam membaca dan dapat memiliki nilai yang bermakna bagi pembaca (Hasna, 2020). Dalam novel Maysuri karya Nadjib Z. terdapat karakter membaca berikut data yang didapat:

(16) "aku sudah melakukan shalat malam,lantas berdoa dan membaca Al-Quran”.(hlmn.69)

Dalam data (16) tersebut termasuk dalam kegiatan membaca karena tokoh melakukan kegiatan ibadah setiap harinya disertai dengan membaca surah-surah yang terdapat dalam Al-Quran. Sehingga penulis menyimpulkan data tersebut termasuk dalam membaca.

\subsection{Pembahasan}

Novel Maysuri karya Nadjib Kartapati Z. merupakan cerita terkait keretakan dan konflik keluarga serta keterbaktian seorang anak. Penggunaan tema yang berjudul Maysuri dikarenakan Maysuri sebagai tokoh yang paling penting dalam novel ini. Tokoh maysuri digambarkan dengan orang yang religious,berbakti kepada orang tua serta memegang erat prinsip. Sehingga, novel ini memiliki kesan Pendidikan dalam 
menguatkan karakter pada jenjang SMA/MA/SMK.

Dalam novel yang berjudul Maysuri karya Kartapati Z ini memiliki nilai-nilai karakter yang sangat penting dan dapat dipahami oleh pembaca. Kemudian, berdasarkan hasil penelitian novel Maysuri karya Nadjib Kartapati Z penulis menemukan dua belas pendidikan karakter, yaitu religious, tanggung jawab, hidup sederhana, disiplin, kreatif, jujur, berbakti kepada orangtua, mencari tahu,berhemat,peduli sosial, dan kasih sayang yang dapat dicontoh bagi para pembaca. Nilai-nilai pendidikan yang terkandung dalam novel ini dapat dijadikan materi pendukung dalam kegiatan pembelajaran jenjang SMA/MA/SMK (Irma, 2018).

Pembelajaran sastra dengan media novel pada mata pelajaran Bahasa Indonesia dapat dijadikan untuk mengembangkan kompetensi yang terkait dengan mengidentifikasi, menelaah, dan menjelaskan unsur kebahasaan dan unsur intrinsik dan ekstrinsik. Selain itu,pembelajaran sastra novel juga dapat meningkatkan pendidikan karakter bagi siswa karena dalam novel Maysuri karya Nadjib Kartapati Z isi cerita novel sangat menginspirasi dan memotivasi bagi anak remaja SMA/MA/SMK sehingga tidak terjebak kedalam dunia yang berperilaku tercela. Karakteristik tokoh novel juga tepat jika dijadikan pembelajaran sastra SMA/MA/SMK.

\section{KESIMPULAN}

Berdasarkan 12 data yang ditemukan dalam novel Maysuri karya Maysuri Nadjib Kartapati Z. Nilai-nilai Pendidikan karakter ,meliputi peduli, kasih sayang, empati, religius, tanggungjawab, mencari tahu, jujur, berbakti kepada orangtua, kreatif, hidup sederhana, rajin, membaca. Dalam cerita tokoh maysuri dikenal dengan orang yang taat agama,ramah dan sopan serta berbakti terhadap orang tua. Dengan tokoh maysuri dapat menggambarkan seorang peran anak. Kelebihan dari tokoh maysuri yaitu dapat bersabar disaat sedang mempunyai masalah dan bersyukur apabila mendapat keberuntungan disaat waktu yang tepat. Tokoh ini dapat memberikan beberapa karakter yang dapat diambil bagi pembaca dan dapat diterapkan dalam keluarga dan bermasyarakat.

\section{DAFTAR PUSTAKA}

Achmad Sultoni, H. W. 2020. Pandangan

Dunia Okky Madasari Tentang Pendidikan Karakter dalam Novel Pasung Jiwa dan Implikasinya Terhadap Pembelajaran Sastra di Indonesia. DISASTRA Jurnal 
Pendidikan Bahasa dan Sastra Indonesia, 134.

Alimin, S. S. 2017. Nilai Pendidikan Karakter Kerja Keras Dalam Novel 2 Karya Donny Dhirgantoro. Jurnal Pendidikan Bahasa, 156.

Andriani, F. 2019. Pendidikan Karakter Tokoh Utama dalam Novel Dear Nathan Karya Erisca Febriani. SEMIBA, 118.

Arifin, M. Z. 2019. Nilai Moral Karya Sastra Sebagai Alternatif Pendidikan Karakter (Novel Amuk Wisanggeni Karya Suwito Sarjono). Jurnal Literasi, 30.

Ermina Waruwu, d. 2020. Kajian Sosiologi Sastra dan Nilai Pendidikan Karakter Dalam Novel Orang Miskin Dilarang Sekolah Karya Wiwid Prasetyo. Jurnal Bahasa, 142.

Fauliyah, F. 2020. Nilai-Nilai Pendidikan Karakter Dalam Novel Anak-Anak Langit Untuk Membina Karakter Siswa Di Madrasah Ibtidaiyah. Jurnal Pendidikan Guru MI, 98.

Hasna, N. F. 2020. Pendidikan Karakter Dalam Novel Sunset Bersama ROSIE Karya Tere Liye Kajian Sosiologi Sastra. SUKMA:Jurnal Pendidikan, 188.

Husna, N. F. 2020. Pendidikan Karakter Dalam Novel Sunset Bersama Rosie Karya Tere Liye Kajian
Sosiologi Sastra. Jurnal Pendidikan, 190.

Indar Agus Susilowati, E. S. 2019. NilaiNilai Pendidikan Karakter dalam Novel Sang Pemimpi Karya Andrea Hirata Sebagai Alternatif Bahan Ajar Sastra di SMA. Jurnal Bahasa, Sastra dan Pengajarannya, 219.

Irma, C. N. 2018. Nilai-Nilai Pendidikan Karakter dalam Novel Ibuk Karya Iwan Setyawan. Jurnal Bahasa, 21.

Isnaniah, D. A. 2020. Nilai Pendidikan Karakter dalam Novel Assalamualaikum Calon Imam Karya Ima Madaniah. Jurnal Kependidikan Dasar Islam Berbasis Sains, 19.

Juanda. 2018. Revitalisasi Nilai Dalam Dongeng Sebagai Wahana Pembentukan Karakter Anak Usia Dini. Jurnal Pustaka Budaya, 15.

Karimah, A. d. 2018. Nilai-Nilai Pendidikan Karakter dalam Novel Madogiwa No Totto-Chan Perspektif KH. Hasyim Asy`ari. Jurnal Pendidikan Islam, 240.

Muhammad Rois Abdulfatah, S. T. 2018. Membentuk Karakter Siswa SMA Melalui Karakter Religius Pada Novel Mahamimpi Anak Negeri Karya Suyatna Pamungkas. PEDAGOGIA:Jurnal Pendidikan, 145. 
Nasional, K. P. 2010. Bahan Pelatihan Penguatan Metodologi

Pembelajaran Berdasarkan Nilai-

Nilai Budaya untuk membentuk daya saing dan karakter bangsa.

Jakarta: Kementerian Pendidikan Nasional.

Rahmat Gunawan, S. S. 2018. Nilai Pendidikan Karakter Religius Novel Rantaul Muara Karya Ahmad Fuadi. Potensia: Jurnal Kependidikan Islam, 141.

Riko, A. d. 2021. Nilai Pendidikan Karakter dalam Novel Sabtu Bersama Bapak Karya Adhitya Mulya. Jurnal Pendidikan Bahasa dan Sastra Indonesia, 23.

Saptiana Sulastri, H. M. 2020. Nilai Pendidikan Karakter Kerja Keras dalam Novel Tentang Kamu karya Tere Liye. Jurnal Penelitian dan Pengembangan Sains dan Humaniora, 44.

Sari, N. (27). Kekerasan Perempuan Dalam Novel Bak Rambut Dibelah Tujuh Karya Mohammad Makhdlori. Jurnal Literasi, 2.

Sri Utorowati, S. E. 2018. Nilai Pendidikan Karakter Dalam Novel Mahabarata dan Novel Bisma Dewabrata : Sebuah Kajian Intertekstual. Proceeding Of The URECOL, 351.
Tansliova, L. 2018. Nilai-Nilai Karakter Bangsa Pada Novel "Ranah 3 Warna" Dan "Rantau 1 Muara" Karya Ahmad Fuadi Serta Kontribusinya Terhadap Pendidikan Karakter. Genta Mulia, 1.

Tantri, A. A. 2017. Nilai-Nilai Pendidikan Karakter Dalam Novel Tantri (Perempuan Yang Bercerita) Karya Cok Sawitri sebagai Alternatif Pembelajaran Sastra Di Sekolah Dasar. Education and Language Internasional Conference, 59.

Teguh Alif Nurhuda, H. J. 2018. NilaiNilai Pendidikan Karakter Pada Novel SIMPLE MIRACLES Karya Ауи Utami. Jurnal Ilmiah Pendidikan Bahasa, Sastra Indonesia dan Daerah, 14.

Thahar, D. A. 2019. Nilai -Nilai Pendidikan Karakter Dalam Novel Daun Yang Jatuh Tak Pernah Membenci Angin Karya Tere Liye. Jurnal Pendidikan Bahasa Indonesia, 86.

Utaminingsih, R. 2020. Implementasi Pendidikan Karakter dalam Novel Ayah Karya Andrea Hirata Siswa Kelas VI SD NEGERI 3 Mangkujayan Ponorogo Tahun Pelajaran 2016/2017. 85. 